\title{
How 'Digital-born' media cover climate change in comparison to legacy media: A case study of the COP 21 summit in Paris
}

\author{
Painter, James ; Kristiansen, Silje ; Schäfer, Mike S.
}

\begin{abstract}
Climate change is often seen as a remote, complex or 'unobtrusive' topic by the general public - a topic about which many people acquire information mainly from media reporting. However, media landscapes are changing rapidly, particularly with the growth of the internet and social media. A number of new media organisations are challenging traditional media and have gained significant audiences for their environment content. We analyse the coverage by three of these - Huffington Post, Vice and BuzzFeed - of the COP21 summit in Paris at the end of 2015, and compare it with that of traditional media. We show that while the general spectrum of themes is similar across media outlets, there are differences in the volume of the coverage and in the emphasis that is laid on different themes by some, but not all, of the new players compared to traditional media.
\end{abstract}

DOI: https://doi.org/10.1016/j.gloenvcha.2017.11.003

Posted at the Zurich Open Repository and Archive, University of Zurich ZORA URL: https://doi.org/10.5167/uzh-148179

Journal Article

Accepted Version

\section{cc) (1) $\$$}

The following work is licensed under a Creative Commons: Attribution-NonCommercial-NoDerivatives 4.0 International (CC BY-NC-ND 4.0) License.

Originally published at:

Painter, James; Kristiansen, Silje; Schäfer, Mike S. (2018). How 'Digital-born' media cover climate change in comparison to legacy media: A case study of the COP 21 summit in Paris. Global Environmental Change, 48:110.

DOI: https://doi.org/10.1016/j.gloenvcha.2017.11.003 


\section{'Digital-born' media and the coverage of the Paris climate summit}

Abstract: Climate change is often seen as a remote, complex or 'unobtrusive' topic by the general public - a topic about which many people acquire information mainly from media reporting. However, media landscapes are changing rapidly, particularly with the growth of the internet and social media. A number of new media organisations are challenging traditional media and have gained significant audiences for their environment content. We analyse the coverage by three of these - Huffington Post, Vice and BuzzFeed - of the COP21 summit in Paris at the end of 2015, and compare it with that of traditional media. We show that while the general spectrum of themes is similar across media outlets, there are differences in the volume of the coverage and in the emphasis that is laid on different themes by some, but not all, of the new players compared to traditional media.

Key words: climate change; digital media; Paris summit; content analysis

Word count: 7116

\section{Introduction}

Climate change is one of the greatest contemporary challenges for humanity, but at the same time, it is often seen as a remote, complex or 'unobtrusive' topic by the general public (Moser 2010). Many people acquire information about it mainly from media reporting (Schäfer, 2015; Stamm et al., 2000), and media reporting, in turn, shapes public perceptions of climate change (Liu et al., 2011; Sampei and Aoyagi-Usui, 2009).

However, media landscapes are changing dramatically, particularly with the growth of the internet and social media. Starting in the 1990s, the decline of the advertising-funded business model for printed newspapers in many Western countries and two waves of digital disruption caused by the internet and the rise of social media have created conditions conducive to the rise of 'digital-born' news media organisations who started off on digital platforms and are not merely digital extensions of newspapers or broadcasters like websites or apps on smartphones (Brock, 2013). These new 'digital-born' players are very diverse. The main differences lie in the size, reach and resources of these companies, their non-profit or for-profit status, their 
provision of niche or general news, and their local, national or international focus (Nicholls et al., 2016).

In the first wave in the 1990s, companies like Yahoo and MSN acted as portals aggregating news from different sources, and offered additional services like emails and search engines. In the second wave in the late 2000s, different media organisations emerged, often originating from the technology sector, which produced original content (Ibid.). They depend on social media and mobile devices for distributing this content, and on algorithms and search engines for decisions about what content to create, publish and promote (Newman et al., 2016).

These 'second wave' digital-born players include several large for-profit international companies, funded by venture capitalists, technology entrepreneurs or other large media companies. Many have their headquarters in the USA but are rapidly expanding into other languages and media markets. Huffington Post (HuffPo), for example, was founded in 2005. After its acquisition by AOL in 2011 for more than US\$300m, it launched editions in French, German and Spanish with local partners in 2012-13, and is now available in ten languages and 15 countries. BuzzFeed, Mashable, Quartz, Vice and Vox have shown a similar capacity, and desire, to expand their presence internationally (Küng, 2015).

These new players are different to legacy media in terms of their investors and funding models, distribution strategies, corporate organisation and culture, and editorial priorities (Nicholls et al., 2016; Küng, 2015). They also offer a different kind of reporting, making extensive use of Facebook, Pinterest, Snapchat and other social media platforms to distribute content. In addition, they have assigned a high editorial priority to environment coverage partly because it has become marginalised in many legacy media suffering cuts to specialist correspondents (Friedman, 2015; Boykoff and Yulsman, 2013), and partly because the new players are keen to engage more directly with a younger audience interested in the topic (name deleted to maintain the integrity of the review process).

With these developments in mind, this paper examines possible differences in the coverage of climate change between a selection of legacy players and new media outlets by focusing on their reporting of one event, namely the Conference of the Parties (COP) summit in Paris at the end of 2015. Our analysis includes five developed, Western countries (France, Germany, 
Spain, the UK and the USA), mainly because of the commonalities in their media systems, and particularly because of the growing presence of new players in each of these countries.

The two main research questions are to investigate similarities and differences firstly in the volume of coverage between these legacy and new players, and secondly, in the selection of themes they prioritise in their coverage. As a supplement to these main questions, we are also interested in assessing similarities and differences between the new players.

\section{State of Research}

Reporting about science and the environment by traditional or 'legacy' media has been particularly affected by their loss of reach and revenue (Dunwoody, 2014; Schäfer, 2017). The growth of the internet and social media has profoundly changed the ways the public, and particularly younger audiences, seek and consume information about science and the environment online (Brainard, 2015). As a result, there is an obvious imperative to analyse how climate change is presented by digital-born media, how far these presentations and reporting styles differ from legacy media, and what the role of such players in the broader media ecosystem can be (Fahy and Nisbet, 2011).

So far, however, no studies have answered these questions. With regards to digital-born players, social scientists have examined how they change longstanding boundaries between journalism and technology (Carlson and Usher, 2016), how the media systems of different countries influence the formation and success of smaller online news start-ups in Western Europe and the US (Bruno and Nielsen, 2012; Powers and Zambrano, 2016), how their strong presence in countries like France, Germany, Spain and the UK is underpinned by investors interested in long-term, global growth (Nicholls et al., 2016), or how legacy media reacted to the arrival of BuzzFeed as a competitor (Tandoc and Jenkins, 2015). Only a few studies have analysed the content of 'digital-born' players' reporting in comparison to legacy media, such as a six-country comparative study of coverage of the Occupy Movement (Humprecht and Büchel, 2013).

While social scientists have published more than one hundred studies on media reporting of climate change to date, and while this scholarship has increasingly focused on online media (Schäfer and Schlichting, 2014) and analysed a large number of its facets (Schäfer, 2012), digital-born players and their coverage of climate change have not been examined. This is an 
important omission because of the considerable emphasis these players place on climate change as an issue and on their editorial distinctiveness.

Since climate change is a complex, multifaceted phenomenon which can be seen in very different ways (Hulme, 2009a), and since such media presentations have been shown to influence audience perceptions (Spence et al., 2010), a large portion of existing studies has focused on what themes or frames the media have traditionally emphasised or portrayed. Previous research has analysed these themes for print media in the US (Antilla, 2005; Nisbet, 2009), the UK (Doulton and Brown, 2009, Hulme, 2009b), Australia, France, India and Norway (Painter, 2013), Sweden (Olausson, 2009) and other countries (Schäfer, 2015).

In broad terms, these studies have found that variants of the 'disaster' frame, which share an emphasis on general or specific adverse effects from climate change such as sea level rise, are often found in the headline or the body of print media articles (Painter, 2013:46ff). In contrast, variants of a more positive framing of climate change, such as opportunity or optimism, are much less frequent. This mirrors the content of scientific reports, where positive impacts from climate change are seldom found. Also frequently identified in print media coverage in the UK, USA and Australia (but not other countries) are different manifestations of the (scientific) uncertainty frame, categorized as including either descriptions of the 'normal' uncertainties embedded in scientific inquiry, or examples of the different types of climate change 'scepticism' about rising temperatures, their anthropogenic causes or their likely impacts (Painter, 2016).

A comprehensive meta-analysis of frame studies was carried out by O'Neill et al. (2015), where the authors based their choice of frames on a literature review of seven major studies, an examination of the main issue frames circulated by elite actors on issues such as security and health, and on population surveys (O'Neill et al.: Online supplementary Information). They catalogued and integrated these results into a single framework of ten frames appropriate for analysing legacy media coverage and Twitter communication about the presentation of the IPCC AR5 working group and synthesis reports. Among the conclusions of this research was that across all the media types in the USA and the UK they analysed, frames such as Disaster, Uncertain Science, Political or Ideological Struggle, and Settled Science, were more frequently used than Opportunity, Morality and Ethics, Economic or Health (O'Neill et al., 2015: 381). This is perhaps not surprising given that the study focused on a single event, the publication of the 
IPCC reports. However, other studies not restricted to a single event have shown the much greater presence of disaster and uncertainty themes compared to opportunity or risk (Painter, 2013), or a gradual decline in the amount of 'science' coverage compared to 'political' coverage in the New York Times from 1995 to 2010 due to the politicisation of the issue in the USA (Kirilenko and Stepchenkova, 2012).

While a lot has been published about how traditional media frame climate change, little is known about the theme prioritisation of the digital-born news players. Therefore, we focus on BuzzFeed, Huffington Post and Vice, because they are the most widely used of these players and successful across countries. They have increased their market share among online news users in Anglophone countries and elsewhere (Newman et al., 2016), and established their presence in a wide range of countries other than the UK and USA and in languages other than English (name deleted to maintain the integrity of the review process).

Online surveys from 2016 show that all three achieved growth in respondents accessing them for news since 2014 in all five countries we have included in this study, with Huffington Post in particular rising sharply everywhere, and BuzzFeed in the USA and UK (Fletcher, 2016: 31). Indeed, a quarter of all those surveyed in the USA said they had used Huffington Post for news in the last week, compared to $21 \%$ for CNN and 14\% for the New York Times (name deleted to maintain the integrity of the review process). Vice performs less well amongst all age groups, but has considerable success with millennials. Even though the new players are often used as secondary sources when compared to more trusted legacy brands, and for softer news subjects, they are performing better than many legacy media in some markets amongst consumers highly interested in environment news (Fletcher, 2016).

Unlike many legacy media organisations, these new players have appointed new specialist reporters and editors in science and the environment in recent years, who often have a background in legacy media (name deleted to maintain the integrity of the review process). They experiment with a wide range of formats popular on social media including video and other visual representations of news (Kalogeropoulos et al., 2016). They pursue editorial innovation or distinctiveness by selecting different stories, angles or themes, adopting different tones in presenting news, and introducing or emphasising different voices not found as often in legacy media (Nicholls et al., 2016). In contrast to the large number of digital-born niche sites focusing exclusively on the environment or climate change (such as 
CarbonBrief.org, reporterre.net or KlimaRetter.info), BuzzFeed, Huffington Post and Vice reach a considerably wider and more diverse audience, and cover these subjects as part of a general news offer.

\section{Materials and Methods}

\subsection{Country selection}

In order to analyse a comprehensive set of cases and to base our analysis on a broad sample, we examined coverage of COP21 in five countries, in which 'digital-born' players exist in domestic versions, and in which these players have significant roles in the respective media systems. Apart from these criteria, country selection was made following a 'most-similar systems' design (e.g. Esser \& Vliegenthart 2016).

In doing so, it focused on developed, Western countries. The USA and four European countries (France, Germany, Spain and the UK) were chosen for analysis. There are important variations in the pace and nature of the changes to the media landscapes in these five countries, due to technological differences, national specificities and cultural variations. For example, the UK and Germany have strong public sector and legacy private media, but in the UK the private sector media are under more pressure from digital players than in the Germany (Nicholls et al, 2016). Digital-born news media are generally more prominent in Spain and France, which have relatively weak legacy news media. The US stands out for having very weak public sector media and a strong private sector media challenged by more digital-born players (Ibid.).

However, the commonalities are more significant. The first is that in all five countries, social media as a source of news is increasing very fast. They overtook printed newspapers for the first time in the USA in 2014, and by 2016 in France, Spain and the UK (Newman et al., 2016). Germany lagged slightly behind. The second is the rapid growth in the use of smart phones as a way of accessing news. This increased significantly in all five countries in the three years between 2013 and 2016, reaching between 40\% and 50\% of the population (ibid.). The third major change is the growing importance of providing video news to smart phones and other platforms as a priority both for traditional and new media companies, in part driven by better connectivity (Kalogeropoulos et al., 2016). The success of the three digital-born players in this study has been based on taking advantage of this boom in the usage of social media, smart phones and video representations of news. 
Amongst the language versions the three organisations have prioritised are French, German and Spanish, in all cases with country-specific versions as well. Currently, Huffington Post is performing better in Spain and France than in Germany. In France it has formed a partnership with Le Monde, and as mentioned above, has a weekly reach of $13 \%$, making it the seventh most used online site for news. It reaches a similar percentage in Spain (14\%), where it is in partnership with El País. In Germany, where television and traditional brands online or offline remain very strong and social media are less popular, Huffington Post (8\%) and BuzzFeed (2\%) are yet to establish themselves strongly.

\subsection{COP Summits}

We analysed coverage of the 21st UN climate change conference, known as COP21, which took place in Paris in November and December 2015. COP summits receive considerable media attention, partly because of the high stakes and the prominence of the political actors involved (Schmidt et al., 2015). They have been analysed extensively from several different academic approaches (Eide and Kunelius, 2012), including whether they influence public awareness and policy preferences (Bakaki and Bernauer, 2017). One strand of research has found similar newspaper framing of COP summits across very different national contexts (Eide and Kunelius, 2010), which has been explained by the nature of the news production context (uniform media access rules and similar information sources) (Wessler et al., forthcoming), and by the presence of strong networks of co-production (Luck et al., 2016), leading to a 'camp feeling' at COP meetings (Wozniak et al., 2016).

A study of the images used by a range of news organisations in their coverage of COP21 concluded that the imagery fell largely into only two categories: staged protests outside of the COP and politicians/negotiators at work inside the COP (Corner, 2016). So previous research, mostly focusing on newspaper coverage, has found high levels of similarity in frames, sources and imagery across media outlets and countries. What is missing is whether new digital media find new ways of covering global staged events like COP summits, and if so, where the differences lie.

\subsection{Article selection and coding}

Articles about COP21 were selected from the online sites of five media organisations (one leftleaning and one centre or right-leaning legacy medium, Huffington Post, Vice, and BuzzFeed) in the five countries mentioned above (see Table 1). The period chosen was between 
November 25 and December 16, 2015. LexisNexis was used to collect articles from the legacy media. For the 'digital-born' players, a site-specific google search was employed.

\section{Table 1: News outlets included in study by country}

\begin{tabular}{|c|c|c|c|c|c|}
\hline & France & Germany & Spain & UK & USA \\
\hline \multirow{3}{*}{$\begin{array}{l}\text { 'Digital-Born' } \\
\text { Players }\end{array}$} & Huffington Post & Huffington Post & Huffington Post & Huffington Post & Huffington Post \\
\hline & BuzzFeed & BuzzFeed & BuzzFeed & BuzzFeed & BuzzFeed \\
\hline & Vice & Vice & Vice & Vice & Vice \\
\hline $\begin{array}{l}\text { Legacy Player } \\
\text { (left-leaning) }\end{array}$ & Le Monde & $\begin{array}{l}\text { Süddeutsche } \\
\text { Zeitung }\end{array}$ & El País & The Guardian & $\begin{array}{l}\text { New York } \\
\text { Times }\end{array}$ \\
\hline $\begin{array}{l}\text { Legacy Player } \\
\text { (centre or } \\
\text { right-leaning) }\end{array}$ & Le Figaro & $\begin{array}{l}\text { Frankfurter } \\
\text { Allgemeine }\end{array}$ & El Mundo & The Telegraph & USA Today \\
\hline
\end{tabular}

All articles from the selected media containing one of the search words "global warming" or "climate change" as well as one of the search terms "Paris" or "UN summit" (as well as their French, German and Spanish equivalents) were downloaded. This included news articles, editorials, blog posts, and opinion pieces. After exclusion of very short articles, the corpus consisted of 1,883 articles.

All identified Vice and BuzzFeed articles were included in the analysis. For the legacy media and Huffington Post, subsamples were drawn for coding based on media and country quotas in order to reach similarly sized coding samples for each media organisation in each country. Every $4^{\text {th }}$ article of the French Huffington Post and legacy media were coded and every $3^{\text {rd }}$ article of the German Huffington Post and legacy media. The Spanish Huffington Post articles were all coded, as well as every $4^{\text {th }}$ legacy media article. UK and USA had the most coverage; every 3rd Huffington Post article in the UK was coded, every $10^{\text {th }}$ article of the Guardian and every $4^{\text {th }}$ of the Telegraph. For the USA, every $10^{\text {th }}$ Huffington Post article was coded and every $5^{\text {th }}$ for the legacy media. The final coding sample consisted of 81 German, 95 Spanish, 110 French, 116 UK and 125 USA articles, giving a total of 527 articles. For most of our analysis presented below, left-leaning and centre/right-leaning newspapers were aggregated into the category 'legacy media'. The first column of Table 2 shows the breakdown by news outlet for the total population of articles identified by the searches, and then in the second column, the sampled number of articles we coded. 
Every article was coded by one of the five coders, who were trained over several weeks.

Several pre-tests were conducted, and the results of those were compared and discussed within the group of coders and with the project leader. During this process coding instructions were improved and resulted in a codebook enabling high inter-coder reliability. The intercoder reliability test used the Lotus coefficient (Fretwurst, 2015) and for the complete code book it revealed high overall coder agreement of $87 \%$. For the variables reported in this article the overall coder agreement was $90 \%$. Reliability varied between $83 \%$ and $97 \%$ depending on the coding categories. In addition, we used the standardized S-Lotus, which is 'contrasting observed with expected inter-coder agreements' (ibid., p. 7); this showed a slightly lower overall agreement of the variables reported in this study of $81 \%$. The S-Lotus values varied between $60 \%$ and $93 \%$, with only four of the twelve themes having values below $80 \%$ : opportunity' (73\%), 'economy and business' (67\%), 'scientific background' (67\%) and 'climate justice' (60\%).

\section{Table 2: News outlet by volume of coverage and sample size}

\begin{tabular}{|c|c|c|c|}
\hline Country & News outlet & Volume of coverage & Sample size \\
\hline \multirow{5}{*}{$\begin{array}{l}\text { USA } \\
n=125\end{array}$} & New York Times (left) & 110 & 22 \\
\hline & USA Today (centre) & 21 & 20 \\
\hline & Huffington Post & 230 & 23 \\
\hline & BuzzFeed & 28 & 28 \\
\hline & Vice & 33 & 32 \\
\hline \multirow{5}{*}{$\begin{array}{l}\text { UK } \\
n=116\end{array}$} & The Guardian (left) & 361 & 37 \\
\hline & The Telegraph (right) & 63 & 16 \\
\hline & Huffington Post & 75 & 25 \\
\hline & BuzzFeed & 24 & 24 \\
\hline & Vice & 14 & 14 \\
\hline \multirow{5}{*}{$\begin{array}{l}\text { France } \\
n=110\end{array}$} & Le Monde (left) & 202 & 30 \\
\hline & Le Figaro (right) & 149 & 30 \\
\hline & Huffington Post & 157 & 30 \\
\hline & BuzzFeed & 12 & 10 \\
\hline & Vice & 10 & 10 \\
\hline \multirow{5}{*}{$\begin{array}{l}\text { Germany } \\
n=81\end{array}$} & SZ (left) & 65 & 31 \\
\hline & FAZ (right) & 68 & 31 \\
\hline & Huffington Post & 14 & 14 \\
\hline & BuzzFeed & 0 & 0 \\
\hline & Vice & 5 & 5 \\
\hline \multirow{5}{*}{$\begin{array}{l}\text { Spain } \\
\mathrm{n}=95\end{array}$} & El País (left) & 103 & 26 \\
\hline & El Mundo (right) & 95 & 25 \\
\hline & Huffington Post & 37 & 37 \\
\hline & BuzzFeed & 0 & 0 \\
\hline & Vice & 7 & 7 \\
\hline Total & & 1,883 & 527 \\
\hline
\end{tabular}




\subsection{Developing and coding the themes}

We started our selection of climate change themes using the above-mentioned study by O'Neill et al. (2015), while bearing in mind that we needed to capture the more socio-political aspects of a COP summit in more detail. So we also examined the frames or themes identified by other studies of COP summits (e.g. Wessler et al., forthcoming; Eide and Kunelius, 2010). After sampling some of the articles to get a sense of the main themes and through an iterative process, we arrived at the following twelve topics which were prevalent in the media reporting of COP21:

- negotiations, including any descriptions and interpretations of the negotiating process including discussions about whether COP21 was a success or failure;

- scientific background, focusing on scientific descriptions of the characteristics, causes and effects of climate change, including the Assessments Reports of the Intergovernmental Panel on Climate Change (IPCC);

- uncertainty, including both descriptions of 'normal' uncertainties embedded in scientific knowledge as well as instances of climate change 'scepticism' relating to the existence of global warming, its anthropogenic causes or outcomes;

- disasters or catastrophes linked to climate change, such as extreme weather events, sea level rise, water shortages, or Arctic sea ice melt;

- economics and business, including the broad relationship between economies and climate change, the threats to the financial stability of entire nations or individual businesses, disinvestment from fossil fuel initiatives, and the possibility of delinking growth and carbon emissions;

- renewable energy, including any mention of solar, wind, tidal, wave and geothermal energy sources, either in a negative or positive light;

- opportunities provided by taking action on climate, such as investment opportunities offered by new energy sectors and forms of transport, the employment opportunities provided by 'green jobs', new shipping routes in the Arctic, and the social advantages of better health, less air pollution and cleaner cities;

- climate justice, i.e. discussions of responsibilities for different countries or stakeholders to take action, and fair distributions between them relating to mitigation, adaption or alleviation of the consequences of climate change; 
- civil society protests, rallies or demonstrations by civil society either in Paris or elsewhere in the world in favor of action on climate change;

- health impacts, charting the effects climate change has on individual and public health or on specific subpopulations such as elderly people;

- food security, mentioning possible climate change impacts on the availability of food, particularly for poorer groups, from lower yields or higher prices;

- migration, discussing the displacement of individuals or peoples due to the social or economic effects of climate change.

Examples of how these themes appeared in the analysed articles can be seen in Table 3. One article could contain one or more themes, which were also coded. 


\title{
Table 3: Examples of twelve themes appearing in the articles
}

\author{
Negotiations \\ "Despite the fatigue, COP21 goes into extra time" (Le Figaro 11/12/15) \\ "Last hours to find a global climate deal" (Le Monde, 11/12/15) \\ "Merkel wants a price for carbon dioxide" (FAZ 12/01/2015)
}
\begin{tabular}{l|l} 
Scientific & "What scientists really know about climate change" (SZ 11/29/2015)
\end{tabular}
\begin{tabular}{l|l} 
background & "As a scientist, I am ashamed at how little we are doing about climate change" (Telegraph 11/30/2015)
\end{tabular}
Uncertainty/ scepticism
"Paris climate conference: 10 reasons why we shouldn't worry about 'man-made' global warming" (Telegraph, $1 / 12 / 15)$
"Global warming: what should we believe?" (Le Figaro, 11/27/2015)

Disasters or

"Climate emergency" (HuffPo France, 11/12/15)

catastrophes

"A city is being flushed away" (FAZ 30/11/15)
Economics and business
"Fossil fuel companies risk wasting US\$2tn of investors' money, study says" (Guardian, 25/11/2015)
"German steel industry criticizes climate contract" (FAZ 14/12/15)
"Billion dollar stakes at climate poker" (SZ 9/12/15)

\begin{tabular}{|l|l|}
\hline \multirow{3}{*}{$\begin{array}{c}\text { Renewable } \\
\text { energy }\end{array}$} & "Obama Says We Should Double the Money Spent on Clean Energy" (BuzzFeed, 30/11/15) \\
\cline { 2 - 2 } & "On the way towards a de-carbonised world" (HuffPo Germany 29/11/15) \\
\cline { 2 - 3 } & "One trillion dollars for solar power" (SZ 6/12/15) \\
\hline
\end{tabular}

\footnotetext{
Opportunities

The economic advantages of developing a "green economy" (Le Figaro 29/11/2015)

"Paris climate summit and solar energy" (El Mundo, 11/28/2015);
}

\section{Climate justice}

"The People of Melbourne's People's Climate March" (Vice UK, 1/12/15)

"We are increasingly making the connections between environmental stakes and social inequalities" (HuffPo France, $11 / 27 / 2015)$

\begin{tabular}{|l|l|}
\hline \multirow{3}{*}{$\begin{array}{c}\text { Civil society } \\
\text { protests }\end{array}$} & "Toxic Tours and Civil Disobedience: COP21 - Climate Emergency, Dispatch 3" (Vice 6/12/2015) \\
\cline { 2 - 2 } & "Protests, high alert before Paris climate conference" (USA Today 1/12/15) \\
\cline { 2 - 2 } & "Activists occupy the roof of an ICE [train]" (FAZ 28/11/15) \\
\hline
\end{tabular}

Health impacts

"Too Hot for Health: How Health Systems Will Cope With Climate Change" (Huffington Post UK, 1/12/2015) "Global warming is also a health issue" (Le Figaro 2/12/15)

Food security

"The secret history of bananas, and what it tells us about climate change" (Daily Telegraph, 7/12/2015)

"Food security must be a central priority for the COP21" (HuffPo France 17/11/15)

Migration

"For this tiny island, the Paris climate deal may come too late" (BuzzFeed, 13/12/2015)

"How the COP21 can draw on Pacific peoples" (Le Monde 4/12/15) 


\subsection{Data analysis}

Data analysis of coverage volume and themes was carried out using IBM SPSS Statistics version 23. Principal Component Analysis (princomp function) and Pearson's chi-square test for equality of proportion (crosstab function) were performed using MATLAB R2016b, The Mathworks. Figure 2 was generated by plotting the first two components of PCA. PCA 'decomposes the original data into a set of linear variates' (Field, 2013: 675), thus reducing the 12 dimensional theme data into two linear components (PC1 and PC2) and establishing which theme variables contribute to those components. The contribution (score) of each theme for defining the coordinates of the different media in the PCA matrix is shown in Figure 4 in Appendix A.

Significance checks for similarities and differences in the use of themes between legacy and 'digital-born' media were conducted using Pearson's chi-square test for equality of proportion (see Table 5). The cells that are marked red in Table 5 indicate that the amount of coverage of a specific theme is significantly different, $p \leq 0.05$. Pearson's chi-square test was used to analyse if there was a relationship between two categorical variables (Fisher, 1922; Pearson, 1900; Field, 2013).

\section{Results}

\subsection{Volume of Coverage}

Despite being placed in a highly competitive news cycle which included the aftermath of the Paris terrorist attacks, the refugee crisis in Eastern and Central Europe and the Middle East as well as the presidential caucuses in the US, national elections in Spain and regional elections in France, COP21 received a considerable amount of media attention. COP21 coverage by the analysed legacy media, for example, seemed to equal the amount of attention media previously gave to the highly reported COP15 conference in Copenhagen, and clearly exceeded that for COP13 (Eide and Kunelius, 2010). Temporally, coverage across all media exhibits the typical pattern of event-centred 'issue attention cycles' (Schmidt et al., 2013), with most attention for the start and the end of the conference, i.e. on the agreement on 12 December, 2015.

Notably, however, the volume of coverage differed strongly between media organisations (see Figure 1). Legacy media covered COP21 most intensively, with 1,298 or approximately twothirds of all articles published in the analysed media appearing there. As shown in previous 
studies (Carvalho, 2007; Howard-Williams, 2009), left-leaning legacy media cover climate change more than right-leaning ones, in the case of COP21 by a factor of more than two (841 compared to 396). Among 'digital-born' players, Huffington Post's coverage was by far the most extensive. In the USA, it had the most coverage by some margin, and the second largest in the UK and France (see Table 2). Across all five countries, it published 513 articles, which was the highest amount by a single media brand.

\section{Figure 1: Volume of coverage}
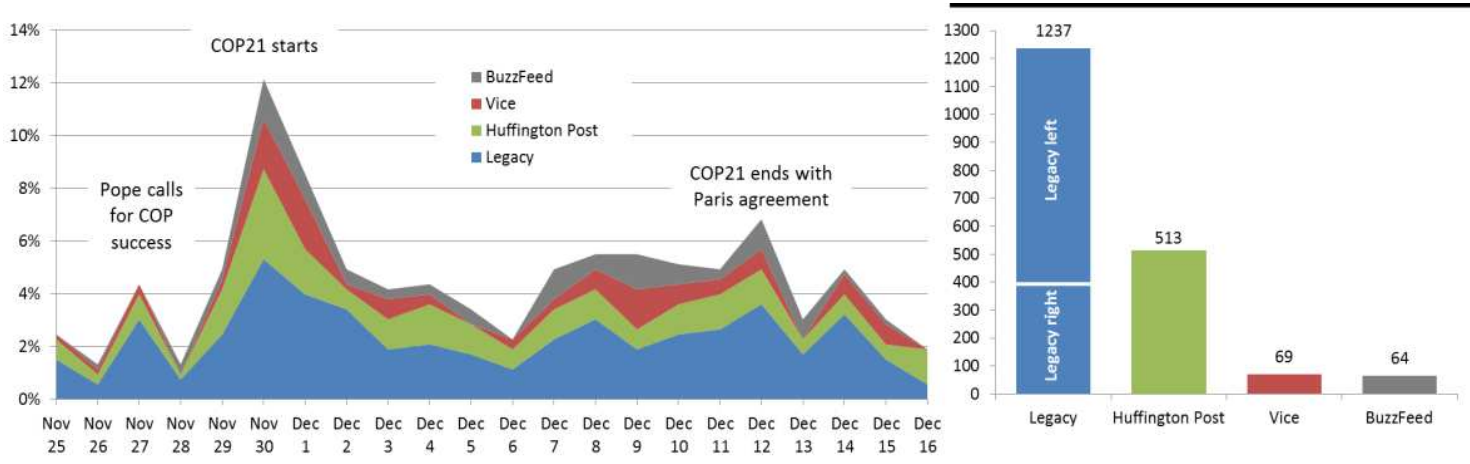

Left: Distribution of coded articles over time ( $\mathrm{N}=527)$. Right: Number of all published articles in the different media organisations ( $N=1,883$, number for legacy-right/centre $=396$, for legacy-left 841 ).

\subsection{Themes}

The media organisations also differed in the themes they emphasised in their coverage to discuss and interpret COP21 or climate change. Overall, the negotiations (46\%), disaster/catastrophe (44\%) and climate justice (40\%) themes were given the highest average amount of coverage across all media, while uncertainty (13\%), migration and displacement $(12 \%)$, food security $(11 \%)$, and health impacts $(11 \%)$ were the least covered themes (see Table 4). But further analysis reveals clear media differences. In order to show this graphically a matrix was generated, which holds the aggregated frequencies of the twelve coded themes per media organisation or type. A Principal Component Analysis (PCA) was used to reduce data dimensionality across all twelve themes, and the first two principal components explain 
$94 \%$ of theme variance ${ }^{1}$. The Kaiser-Meyer-Olkin measure verified the sampling adequacy for the analysis, $\mathrm{KMO}>0.9^{2}$.

Placing the analysed media in a matrix spanned by these two principal components reveals strong similarities between legacy media and Huffington Post (see Figure 2). In contrast, Vice and BuzzFeed are set apart from each other as well as from legacy media and Huffington Post.

\section{Figure 2: Media similarity by principal component analysis}

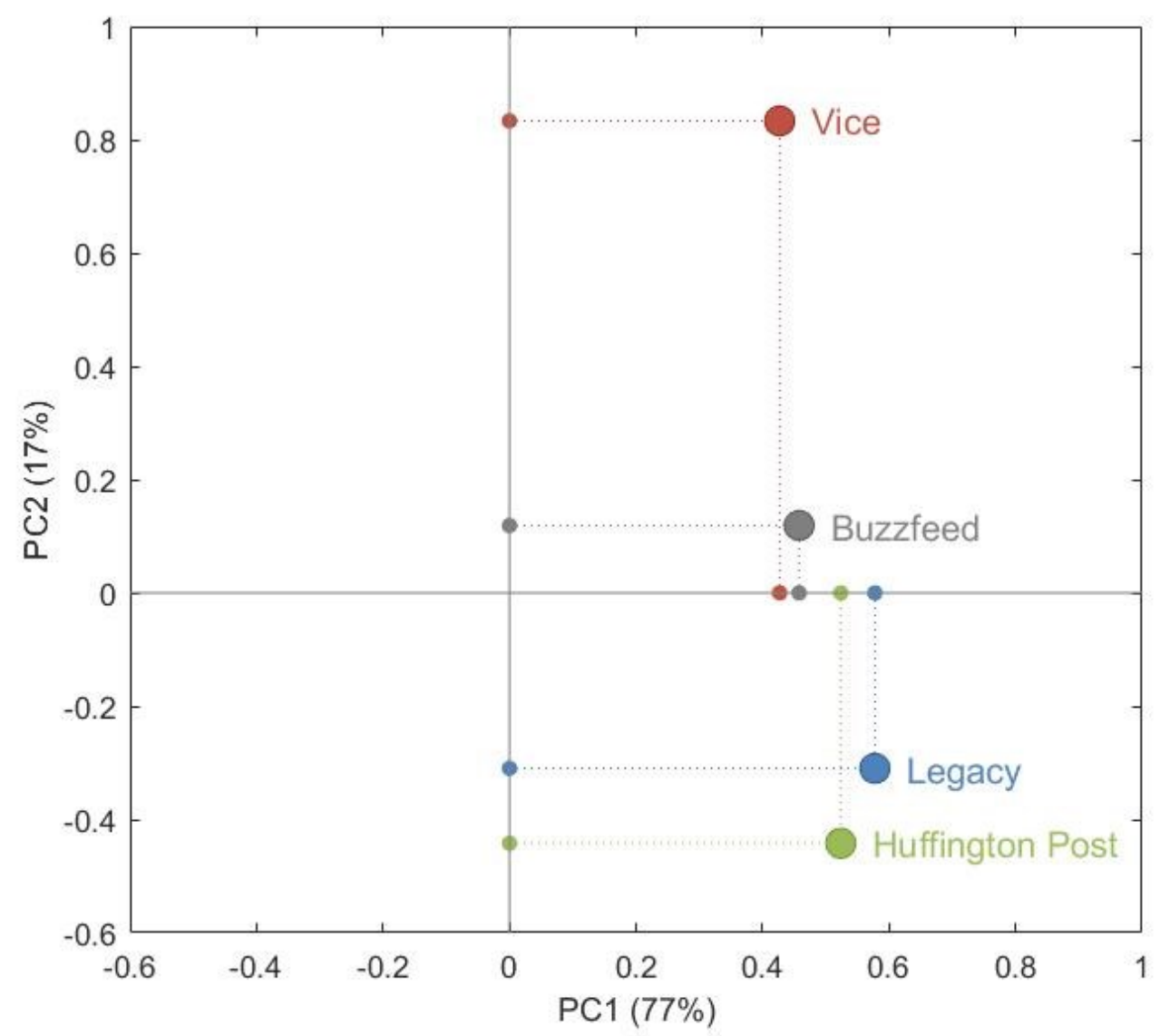

These similarities and differences can be further illuminated by a detailed look at the percentages in which the analysed media used each of the twelve themes. The spider graph in Figure 3 visually captures the distribution of themes based on the percentage figures shown in Table 4. In terms of similarities, the themes disaster/catastrophe and scientific background

\footnotetext{
${ }^{1}$ The themes Negotiations, Economics \& business and Opportunity have the highest loadings on PC1 and a Cronbach's alpha of 0.95 . The themes Civil society protests, Renewable energy, Migration \& displacement, Health impacts and Food security have the highest loadings on PC2 and a Cronbach's alpha of 0.82 .

${ }^{2}$ We used Trujillo-Ortiz et al. 2006 to calculate the KMO in MATLAB.
} 
were covered equally often across legacy and 'digital-born' media. However, in general, legacy media and Huffington Post covered a broader range of themes more extensively than Vice and BuzzFeed. They focused to a similar extent on the political and economic background to COP21. This is evident in the high percentage of mentions of the negotiations, economics and business, and opportunities. Vice and BuzzFeed both covered a smaller spectrum of themes, and did so focusing on different aspects.

\section{Figure 3: Themes covered by the different media}

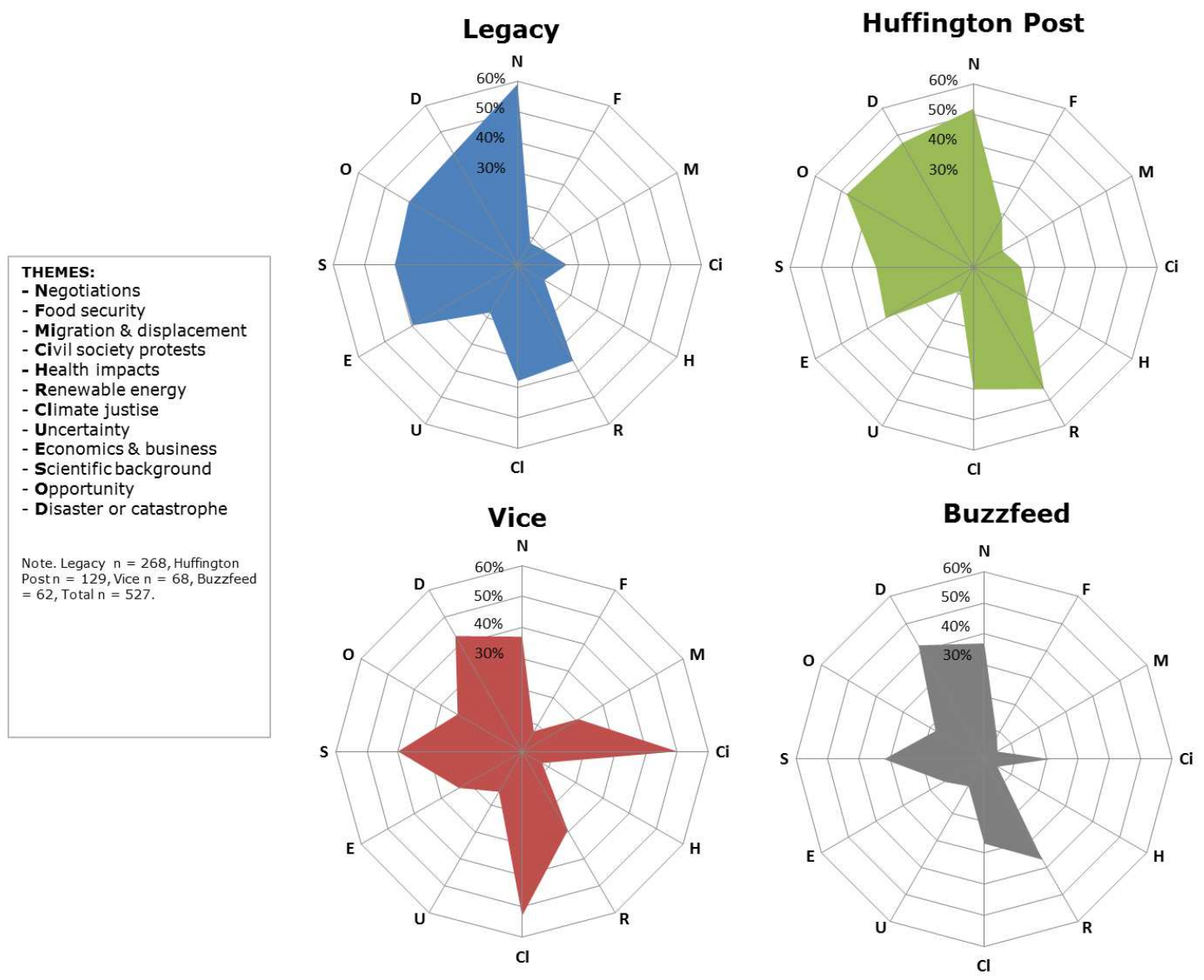


Table 4: Percentages of theme coverage by media

\begin{tabular}{|c|c|c|c|c|c|c|c|c|c|c|c|c|}
\hline Medium & Negotiations & $\begin{array}{c}\text { Food } \\
\text { security }\end{array}$ & $\begin{array}{c}\text { Migration \& } \\
\text { displacement }\end{array}$ & $\begin{array}{c}\text { Civil } \\
\text { society } \\
\text { protests }\end{array}$ & $\begin{array}{l}\text { Health } \\
\text { impacts }\end{array}$ & $\begin{array}{c}\text { Renewable } \\
\text { energy }\end{array}$ & $\begin{array}{l}\text { Climate } \\
\text { justice }\end{array}$ & Uncertainty & $\begin{array}{c}\text { Economics } \\
\& \\
\text { business } \\
\end{array}$ & $\begin{array}{c}\text { Scientific } \\
\text { background }\end{array}$ & Opportunity & $\begin{array}{l}\text { Disaster or } \\
\text { catastrophe }\end{array}$ \\
\hline Legacy & $59 \%$ & $8 \%$ & $10 \%$ & $16 \%$ & $10 \%$ & $36 \%$ & $38 \%$ & $18 \%$ & $40 \%$ & $40 \%$ & $41 \%$ & $42 \%$ \\
\hline Huffington Post & $52 \%$ & $19 \%$ & $11 \%$ & $16 \%$ & $20 \%$ & $46 \%$ & $40 \%$ & $9 \%$ & $33 \%$ & $32 \%$ & $48 \%$ & $47 \%$ \\
\hline Vice & $37 \%$ & $7 \%$ & $21 \%$ & $50 \%$ & $7 \%$ & $29 \%$ & $53 \%$ & $15 \%$ & $24 \%$ & $40 \%$ & $24 \%$ & $43 \%$ \\
\hline BuzzFeed & $37 \%$ & $8 \%$ & $5 \%$ & $21 \%$ & $5 \%$ & $37 \%$ & $27 \%$ & $10 \%$ & $15 \%$ & $32 \%$ & $18 \%$ & $42 \%$ \\
\hline Theme average & $46 \%$ & $11 \%$ & $12 \%$ & $26 \%$ & $11 \%$ & $37 \%$ & $40 \%$ & $13 \%$ & $28 \%$ & $36 \%$ & $33 \%$ & $44 \%$ \\
\hline
\end{tabular}


Table 5 uses Pearson's chi-square test for equality of proportion to illustrate more clearly where the differences in themes are statistically significant. The squares marked in shades of red show where the differences are significant: the darker the shade of red, the smaller the $p$ value and therefore the more robust statistical difference. The bottom row of Table 5 shows the degree of difference between different media combinations, whereas the final column shows how the presence of each theme differs in the variety of media comparisons.

From Table 5 we can see that as with the PCA analysis, Huffington Post shows strong thematic similarities to the legacy media in our sample. As column 1 of Table 5 illustrates, there were only three significant differences between them, and two of these were in the relatively 'minor' topics of health impacts and food security. The third difference was that Huffington Post included the uncertainty theme less than the legacy media ( $9 \%$ compared to $18 \%$, see Table 4), a finding we shall return to in the Discussion section below. 
Table 5: Pearson's chi-square test for equality of proportion in coverage between any two media

\begin{tabular}{|c|c|c|c|c|c|c|c|}
\hline$p$-values & $\begin{array}{l}\text { Leg- } \\
\text { Huff }\end{array}$ & $\begin{array}{l}\text { Leg- } \\
\text { Vice }\end{array}$ & $\begin{array}{l}\text { Leg- } \\
\text { Buzz }\end{array}$ & $\begin{array}{l}\text { Huff- } \\
\text { Vice }\end{array}$ & $\begin{array}{l}\text { Huff- } \\
\text { Buzz }\end{array}$ & $\begin{array}{l}\text { Vice- } \\
\text { Buzz }\end{array}$ & $\begin{array}{c}\text { Total significant } \\
\text { differences }\end{array}$ \\
\hline Opportunity & 0.164 & 0.009 & 0.001 & 0.001 & 0.000 & 0.417 & 4 \\
\hline Negotiations & 0.211 & 0.001 & 0.002 & 0.042 & 0.054 & 0.969 & 3 \\
\hline Economy \& business & 0.231 & 0.014 & 0.000 & 0.153 & 0.006 & 0.193 & 3 \\
\hline Health impacts & 0.006 & 0.495 & 0.196 & 0.019 & 0.006 & 0.551 & 3 \\
\hline Civil society protests & 0.890 & 0.000 & 0.352 & 0.000 & 0.350 & 0.001 & 3 \\
\hline Climate justice & 0.777 & 0.026 & 0.116 & 0.072 & 0.102 & 0.003 & 2 \\
\hline Food security & 0.002 & 0.817 & 0.970 & 0.034 & 0.057 & 0.879 & 2 \\
\hline $\begin{array}{c}\text { Migration \& } \\
\text { displacement }\end{array}$ & 0.721 & 0.013 & 0.223 & 0.063 & 0.172 & 0.008 & 2 \\
\hline Renewable energy & 0.068 & 0.294 & 0.894 & 0.026 & 0.259 & 0.352 & 1 \\
\hline Uncertainty & 0.014 & 0.532 & 0.114 & 0.182 & 0.794 & 0.383 & 1 \\
\hline Scientific background & 0.116 & 0.974 & 0.263 & 0.266 & 0.947 & 0.377 & 0 \\
\hline Disaster \& catastrophe & 0.374 & 0.898 & 0.983 & 0.604 & 0.552 & 0.935 & 0 \\
\hline Total significant differences & 3 & 6 & 3 & 6 & 3 & 3 & \\
\hline
\end{tabular}

Row 1 of Table 5 shows that opportunity was the theme that showed significant differences in the most media combinations (four). These were most marked between Huffington Post on the one hand, and Vice and BuzzFeed on the other - although they are also marked between legacy media and the latter two new players. The only media combinations that did not show significant differences in the amount of attention directed to negotiations was between legacy and Huffington Post, and between Vice and BuzzFeed. In percentage terms, Table 4 shows that the opportunity theme was covered the most in Huffington Post ( $48 \%$ compared to $41 \%$ for legacy, and around 20\% for Vice and BuzzFeed). Renewable energy, which could be seen as an opportunity, appeared in nearly half (46\%) of Huffington Post's articles. However, all the media, except Vice, had relatively high coverage of renewables. HuffPo was leading this trend, but did not differ significantly except in comparison with Vice.

Row 2 of Table 5 shows a significant difference between BuzzFeed/Vice on the one hand, and the other media on the other, in the amount of attention they paid to the negotiations. We see these differences between legacy-Vice, legacy-BuzzFeed, and HuffPo-Vice. The differences were particularly apparent in the contrast with legacy media. In percentage terms, Table 4 shows that BuzzFeed and Vice dedicated comparatively little, just over a third, of their coverage to the negotiations (37\% each), compared to legacy media (59\%) and Huffington Post (52\%). 
Row 5 also points to statistically significant differences in the amount of space given to civil society protests. Vice stands out in sharp contrast to all the other media organisations or media types. As Table 4 shows, half of all of Vice's coverage included this theme, compared to between $16 \%$ and $21 \%$ for the other outlets. Indeed, this was one of the reasons why Vice stood out most in comparison to the other media organisations. As the last row shows, Vice showed six statistically significant differences with both legacy media and Huffington Post, a result also visible in the PCA analysis found in Figure 2 (where Vice is furthest away from the other media, particularly legacy and Huffington Post, on both axes). In addition to its emphasis on coverage of the protests, it focused more on climate justice (53\%) than legacy media (38\%) and BuzzFeed (23\%). In contrast, BuzzFeed was more akin to legacy media and Huffington Post in not giving as much attention to the protests $(21 \%)$ or climate justice $(27 \%)$.

\section{Discussion and Conclusion}

COP summits have been described as special events for the media, with similar sources and material available, constrained options for coverage and resulting similarities in the coverage of legacy media. In particular, previous studies of COPs have shown a similar treatment by media organisations across different countries. For example, an emphasis on four overarching themes (global warming victims, civil society demands, political negotiations, and sustainably energy) was found by a detailed analysis of COPs 16-19 in newspaper articles in Brazil, Germany, India, South Africa and the USA (Wessler et al., forthcoming). Similarly, a study of COP21 showed that many themes appeared consistently across the newspapers in a selection of 13 developed and developing countries; the five most common of these were negotiations, effects of climate change, civil society engagement, mitigation and public figures (Gurwitt et al., 2017).

While our study shows a considerable overlap in COP21 coverage as well, it also demonstrates some differences between some of the recently emerged 'digital-born' players and legacy media, and between the new players themselves. As regards our first research question about the volume of coverage, the stand-out result was the large amount of coverage given to the summit by Huffington Post, reflecting perhaps its strong editorial focus on environmental issues, its business model based on producing a sizeable volume of content (to boost reach and attract advertising) and its desire to compete head-on with legacy media. Vice's and 
BuzzFeed's coverage was notably smaller. Both outlets were more selective in their coverage, likely driven by their desire to be different from legacy media and to publish content that would be widely shared by younger audiences on social media platforms, which shapes the type of coverage they offer (name deleted to maintain the integrity of the review process).

As regards our second research question, both the PCA and Chi-square test analysis showed that there were many similarities between Huffington Post and legacy media in the amount of attention directed to the different themes. Although all new players, including Huffington Post, seek editorial distinctiveness (Nicholls et al., 2016: 31), it seems that Huffington Post followed similar editorial priorities to legacy media in its coverage of the Paris summit. In part, this may be a result of the constraining nature of covering such a time- and spatially-fixed event, but it may also be a factor that Huffington Post sees itself as a direct competitor to legacy media, rather than seeking to complement their content with different themes or angles (as Vice and BuzzFeed seem to do).

We included opportunity as a theme partly because it is one of the frames identified by authors as supporting self-efficacy amongst audiences, whereas 'disaster' treatments can often lead to disengagement ( $O^{\prime}$ Neill et al., 2013). So, it is significant that Huffington Post does not stand out particularly from the legacy media in our sample for a more positive, solutionsoriented approach to covering climate change, despite the stated policy of Huffington Post former editor-in-chief, Arianna Huffington, of covering more solutions to the climate change challenge during COP21 (name deleted to maintain the integrity of the review process). However, Huffington Post does stand out from the two other new media players in this respect.

One minor difference between Huffington Post and the legacy media is the lower presence of the uncertainty theme. In Anglophone media coverage in general, the uncertainty theme has been found to be common in the coverage of the IPCC reports in particular ( $\mathrm{O}^{\prime} \mathrm{Neill}$ et al., 2015), and of climate change in general (Painter, 2016). However, this theme was only present in an average of $13 \%$ of the analysed sample, a considerably lower percentage than other studies, which is perhaps explained by the low presence of sceptics at the conference. Whereas Huffington Post was below the average (9\%), legacy media were above (18\%), which was mostly explained by the presence of sceptical voices in the right-leaning media in the UK and USA, including commentaries by sceptics (Painter, 2016). The key point here is that 
Huffington Post has a stated policy of not giving voice to sceptics; this follows a more general trend of left-leaning news outlets being much less sympathetic to sceptics than right-leaning ones (ibid.).

Whereas Huffington Post emerges as closer to the theme profile of legacy media in our sample, this is not the case for Vice and BuzzFeed in some areas. These two new players in part define themselves as being different to legacy media, and set out to cover topics or angles to stories which distinguish themselves from traditional media coverage (name deleted to maintain the integrity of the review process). This may go some way to explaining the lower level of coverage of the negotiations, as their editors and reporters knew this aspect would be well covered by traditional media; such a theme, which frequently involves pictures of politicians and negotiators (Corner, 2016), is probably much less appealing to a younger audience who are unlikely to share such content.

Vice stood out for pursuing a different theme selection in comparison to all the other media outlets. For example, it covered the civil society protests outside the formal negotiations in Paris considerably more than the other media outlets. Indeed, a major component of its coverage was a series of six video reports called 'Climate Emergency Dispatches', which lasted between 7 and 16 minutes (name deleted to maintain the integrity of the review process). This approach was likely driven by a desire to appeal to its younger and politically partisan target audience. This may help to explain the strong presence of the climate justice theme too, compared to some of the other outlets. In contrast, and despite a similarly young target audience, BuzzFeed gave much less attention to the protests, and in general gave less attention to the different themes.

Vice's decision to emphasise the civil society protests is important because previous studies have shown that legacy media under-represent citizen voices in general (e.g. Ferree et al., 2002) and in climate change reporting as well (e.g. Eide et al. 2010), and that they focus strongly on scientific and political aspects of climate change and pay less attention to civil society issues like climate justice and perspectives from developing countries (e.g. Schmidt and Schäfer, 2015). So Vice, and to a certain extent Huffington Post, have expanded this range of viewpoints, and emphasise perspectives in the public debate which were less prominent before. 
In general, our conclusions also show that lumping together 'new players' or 'digital-born media' into one category is not useful. As we have shown, in many respects Huffington Post is more akin to legacy media in its treatments of themes, and Vice is more different to legacy media and Huffington Post than it is to BuzzFeed. More analysis is needed of how the differences sketched out in Section 1 in their funding models, distribution strategies, corporate organisation and culture, and editorial priorities affect their coverage of climate change so that they end up doing it differently.

In this study, we did not analyse other potential differences between legacy media and new players. However, there is substantial evidence that the three new players in this study are distinct to legacy media in their adoption of different journalistic tones and quoting of different voices (Russell and Howarth, 2016), and in their emphasis on multimedia content and particularly visuals (León and Erviti, 2016). We have focused on Huffington Post, Vice and BuzzFeed, but additional research is needed on other new digital players like Vox who place considerable editorial importance on background 'explainers' about climate change, and on graphical representations of climate science. This will also help climate change and environmental movements understand the opportunities that the new media landscape offers in terms of taking advantage of social media, by understanding what sort of (different) content gets produced by the new players, what gets shared, and why. 


\section{Appendix A}

Figure 4 PCA scores

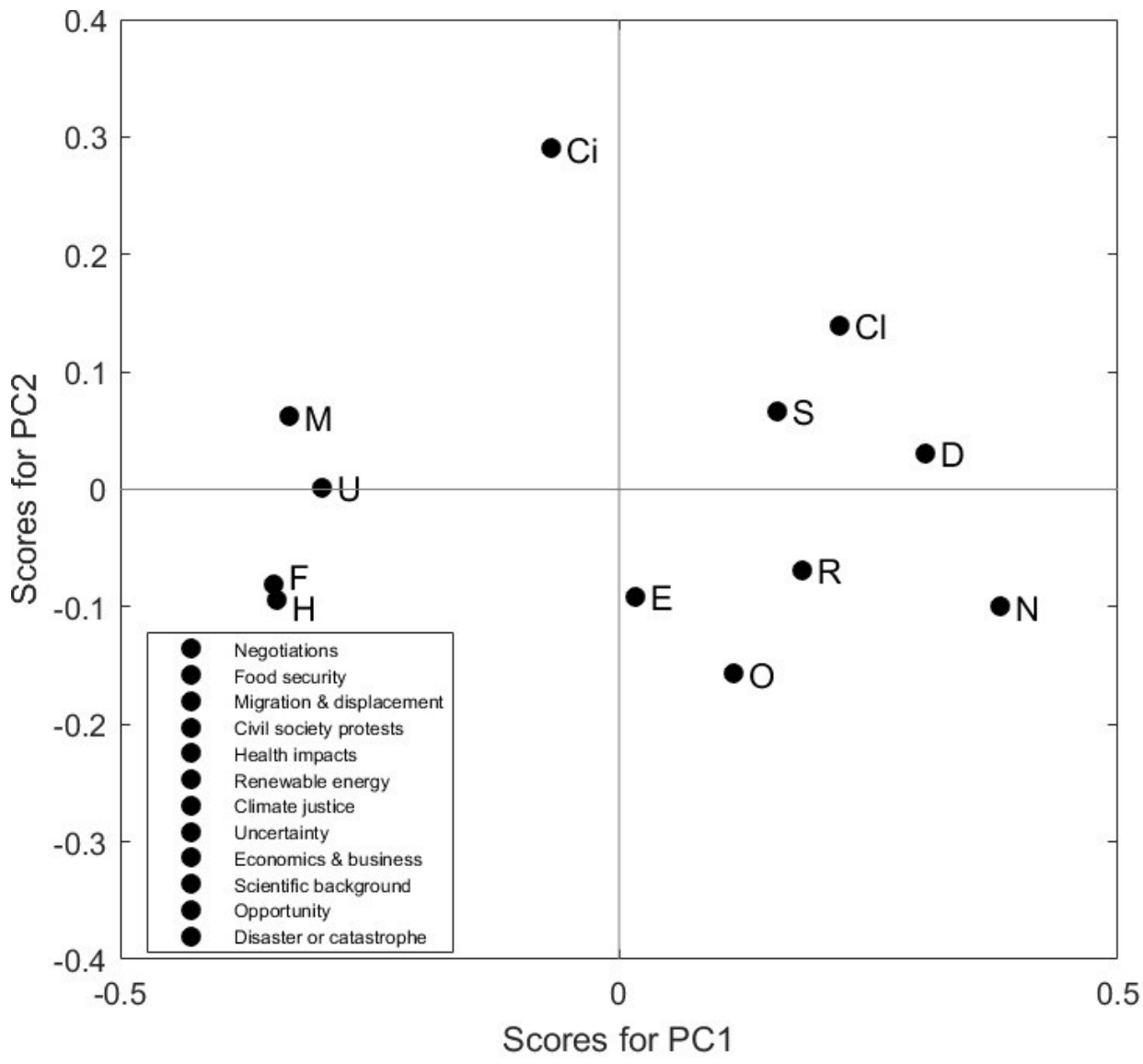




\section{References}

Antilla, L. (2005) Climate of scepticism: US newspaper coverage of the science of climate change. Global Environmental Change 15 (4), 338-352.

Bakaki, Z. \& Bernauer, T. (2017) Do global climate summits influence public awareness and policy preferences concerning climate change? Environmental Politics 26 (1), 1-26.

Boykoff, M. T. \& Yulsman, T. (2013) Political economy, media, and climate change: sinews of modern life. WIREs Climate Change 4, 359-371. Available from: doi: $10.1002 / w c c .233$ [12 ${ }^{\text {th }}$ February 2017].

Brainard, C. (2015). The changing ecology of news and news organisations: implications for environmental news. In Hansen, A. \& Cox, R. (eds.) The Routledge Handbook of Environment and Communication, London and New York, Routledge, pp 168-175.

Brock, G. (2013) Out of Print: Newspapers, Journalism and the Business of News in the Digital Age. London, Kogan Page.

Bruno, N. \& Nielsen, R. K. (2012) Survival Is Success: Journalistic Online Start-Ups in Western Europe. Oxford, Reuters Institute for the Study of Journalism.

Carlson, M. \& Usher, N. (2016) News Startups as Agents of Innovation. Digital Journalism 4 (5), 563-581.

Carvalho, A. (2007) Ideological cultures and media discourses on scientific knowledge: rereading news on climate change. Public Understanding of Science 16 (2), 223-243.

Corner, A. (2016) Climate Visuals. Towards a new visual language for climate change: An evidence-based Briefing for COP22 and beyond. Oxford, Climate Outreach.

Doulton, H., \& Brown, K. (2009) Ten years to prevent catastrophe? Discourses of climate change and international development in the UK press. Global Environment Change 19, 191 202. Available from: doi:10.1016/j.gloenvcha.2008.10.004.

Dunwoody, S. (2014). Science Journalism: Prospects in the Digital Age. In Bucchi M. \& Trench B. (eds.) Routledge Handbook of Public Communication of Science and Technology, London and New York, Routledge, pp. 27-39.

Eide, E. \& Kunelius, R. (eds.) (2012) Media Meets Climate: the Global Challenge for Journalism. Göteborg, Nordicom.

Eide, E., Risto, K. \& Ville, K. (eds.) (2010) Global climate-local journalisms: A Transnational Study of how Media make Sense of Climate Summits. Bochum, Projektverlag.

Esser, F., \& Vliegenthart, R. (2016) Comparative Research Methods. In: Matthes, J., Potter, R. \& Davis C. S. (eds.) International Encyclopedia of Communication Research Methods. London, Wiley-Blackwell, forthcoming. 
Fahy D. \& Nisbet M. (2011) The science journalist online: Shifting roles and emerging practices. Journalism 12 (7), 778-793.

Ferree, M. M., Gamson W.A., Gerhards J. \& Rucht D. (2002) Shaping abortion discourse: Democracy and the public sphere in Germany and the United States. Cambridge, Cambridge University Press.

Field, A. (2013) Discovering statistics using IBM SPSS statistics. $4^{\text {th }}$ edition. Los Angeles, Sage.

Fisher, R. A. (1922) On the interpretation of chi square from contingency tables, and the calculation of P. Journal of the Royal Statistical Society 85, 87-94.

Fletcher, R. (2016) The public and news about the environment. In: Painter et al. (eds.) Something old, something new: digital media and the coverage of climate change. Oxford, Reuters Institute for the Study of Journalism, pp. 24-36.

Fretwurst, B. (2015) Lotus Manual. Reliability and Accuracy with SPSS. Available from: http://www.iakom.ch/Lotus/LotusManualEng.pdf

Friedman, S. M. (2015) The Changing Face of Environmental Journalism in The United States. In Hansen, A. \& Cox, R. (eds.) The Routledge Handbook of Environment and Communication, London and New York, Routledge, pp. 144-57.

Gurwitt S., Malkki K., \& Mitra M., (2017). Global issue, developed country bias: the Paris climate conference as covered by daily print news organisations in 13 nations. Climatic Change, DOI 10.1007/s10584-017-2004-2.

Howard-Williams, R. (2009) Ideological Construction of Climate Change in Australian and New Zealand NewsPapers. In Boyce T. \& Lewis J. (eds.) Climate Change and the Media, New York, Peter Lang, pp. 28-42.

Hulme, M. (2009a) Why we disagree about climate change: understanding controversy, inaction and opportunity. Cambridge, Cambridge Univ. Press.

Hulme, M. (2009b). Mediated Messages about Climate Change: Reporting the IPCC Fourth Assessment in the UK Print Media. In Boyce T. \& Lewis J. (eds.) Climate Change and the Media, New York, Peter Lang, pp. 117-128.

Humprecht, E. \& Büchel F. (2013) More of the Same or Marketplace of Opinions? A CrossNational Comparison of Diversity in Online News Reporting. International Journal of Press/Politics 18 (4), 436-61.

Liu, X., Lindquist, E., \& Vedlitz, A. (2011) Explaining Media and Congressional Attention to Global Climate Change, 1969-2005: An Empirical Test of Agenda-Setting Theory. Political Research Quarterly 64 (2), 405-419.

Luck, J., Wozniak, A., \& Wessler H. (2016) Networks of Coproduction: How journalists and Environmental NGOs Create Common Interpretations of the UN Climate Change Conferences. International Journal of Press/Politics 21 (1), 25-47. 
Kalogeropoulos, A., Cherubini, F., \& Newman, N. (2016) The future of online news video. Oxford, Reuters Institute for the Study of Journalism.

Küng, L. (2015) Innovators in Digital News. Oxford, Reuters Institute for the Study of Journalism.

León B. \& Erviti M.C. (2016) A climate summit in pictures. In: Painter et al. (eds.) Something old, something new: digital media and the coverage of climate change. Oxford, Reuters Institute for the Study of Journalism, pp. 63-72.

Moser, S. C. (2010) Communicating climate change: history, challenges, process and future directions. WIREs Climate Change 1 (1), 31-53.

Newman, N., Fletcher R., Levy D. \& Nielsen, R.K. (2016) Digital News Report. Oxford, Reuters Institute for the Study of Journalism.

Nicholls, T., Shabbir N., \& Nielsen R.K. (2016) Digital-born News Media in Europe. Oxford, Reuters Institute for the Study of Journalism.

Nisbet, M. C. (2009) Communicating Climate Change: Why frames matter to public engagement. Environment 51 (2), 514-518.

Olausson, U. (2009) Global warming - global responsibility? Media frames of collective action and scientific certainty. Public Understanding of Science 18 (4), 421-436.

O'Neill, S., Boykoff M., Day S., \& Niemeyer S. (2013). On the use of imagery for climate change engagement. Glob Environ Change 23, 413-421.

O’Neill, S., Williams, H. T., Kurz, T., Wiersma, B., \& Boykoff, M. (2015) Dominant frames in legacy and social media coverage of the IPCC Fifth Assessment Report. Nature Climate Change, 5 (4), 380-385.

Painter, J. (2013) Climate change in the media: reporting risk and uncertainty. Oxford, I.B.Tauris and Reuters Institute for the Study of Journalism.

Painter, J. (2014) Disaster Averted? Television Coverage of the 2013/14 IPCC's Climate Change Reports. Oxford, Reuters Institute for the Study of Journalism.

Painter, J. (2016) Journalistic Depictions of Uncertainty about Climate Change Across Countries. Oxford Research Encyclopedias. doi: 10.1093/acrefore/9780190228620.013.346.

Pearson, K. (1900) On the criterion that a given system of deviations from the probable in the case of a correlated system of variables is such that it can be reasonably supposed to have arisen from random sampling. Philosophical Magazine 50 (5), 157-175.

Powers, M. \& Zambrano, S. V. (2016) Explaining the Formation of Online News Startups in France and the United States: A Field Analysis. Journal of Communication 66 (5), 857-77.

Russell A. \& Howarth C. (2016) Similarities and differences in sources, tone and advocacy. In: Painter et al. (eds.) Something old, something new: digital media and the coverage of climate change. Oxford, Reuters Institute for the Study of Journalism, pp. 73-83. 
Sampei, Y., \& Aoyagi-Usui, M. (2009) Mass-media coverage, its influence on public awareness of climate-change issues, and implications for Japan's national campaign to reduce greenhouse gas emissions. Global Environmental Change 19 (2), 203-212.

Schäfer, M. \& Schlichting I. (2014) Media Representations of Climate Change: A Meta-Analysis of the Research Field. Environmental Communication 8 (2), 142-160.

Schäfer, M. S. (2012) Online communication on climate change and climate politics: a literature review. WIREs Climate Change 3 (6), 527-543.

Schäfer, M. S. (2015) Climate change and the media. In: Wright, J. (ed.) International Encyclopedia of the Social \& Behavioral Sciences. $2^{\text {nd }}$ edition. Amsterdam etc., Elsevier, pp. 853-859.

Schäfer, M. S. (2017): How Changing Media Structures are Affecting Science News Coverage. In: Hall Jamieson, K., Kahan, K. \& Scheufele, D. (eds.): The Oxford Handbook of the Science of Science Communication. New York, Oxford University Press, pp. 51-57.

Schmidt, A., Ivanova, A., \& Schäfer, M. S. (2013) Media Attention for Climate Change around the World: A Comparative Analysis of Newspaper Coverage in 27 Countries. Global Environmental Change 23, (5), 1233-1248.

Schmidt, A. \& Schäfer, M. S. (2015) Constructions of climate justice in German, Indian and US Media debates. Climatic Change 133 (3), 535-549.

Spence, A., \& Pidgeon, N. (2010) Framing and communicating climate change: The effects of distance and outcome frame manipulations. Global Environmental Change 20 (4), 656-667.

Stamm, K. R., Clark F. \& Eblacas P. R. (2000) Mass communication and public understanding of environmental problems: the case of global warming. Public Understanding of Science 9 (3), 219-237.

Tandoc, E. C. \& Jenkins, J. (2015) The BuzzFeedification of Journalism: How Traditional News Organizations Are Talking About a New Entrant to the Journalistic Field Will Surprise You! Journalism. Online First: 1-19.

Trujillo-Ortiz, A., R. Hernandez-Walls, A. Castro-Perez, K. Barba-Rojo \& A. Otero-Limon (2006). kmo:Kaiser-Meyer-Olkin Measure of Sampling Adequacy. Retrieved from http://www.mathworks.com/matlabcentral/fileexchange/loadFile.do?objectld=12736

Wessler, H., Wozniak, A., Hofer, L., \& Lück, J. (forthcoming) Combining Text and Images in Framing Climate Change in the News: A comparison of five democracies around the world. International Journal of Press/Politics.

Wozniak, A., Wessler, H., \& Luck J. (2016) Who prevails in the visual framing contest about the UN climate change conferences?', Journalism Studies Available from: doi:

10.1080/1461670X.2015.1131129. 